\title{
Global Learning and the School Curriculum
}

\author{
Douglas Bourn, \\ Development Education Research Centre, UCL-IOE,UK
}

\begin{abstract}
The global society of today is one that children and young people are aware of but this has not been fully recognized by education policy-makers despite the efforts and activities of many civil society organisations and the enthusiasms of teachers. Since 2010 in England one government sponsored programme, the Global Learning Programme has been a conscious attempt to equip children and young people with the knowledge and skills to not only understand but actively engage within global issues This Programme is beginning to show the value of a 'whole school' approach in terms of increasing not only knowledge and understanding about the wider world but putting themes such as social justice and concern for the environment as key themes of a child's learning.
\end{abstract}

Keywords: global learning, global citizenship, whole school, globalization, social justice.

\section{Introduction}

Children and young people are growing up in a globalised world. They have instant access to information and knowledge; social media provides them with opportunities for dialogue and communication with their peers elsewhere in the world. Terms like 'being a global citizen' are being used more and more as ways of describing this phenomenon.

The fact of living in a globalised and interdependent world is evident to children and young people from just hearing about refugees and migration into Europe to the ever-present concern with climate change and how economies are subject to the vagaries of global forces.

This relationship to the wider world is something many children and young people are aware of and are concerned about. There is evidence that learning about these areas are popular and well received by young people (Bourn and Brown, 2011; Edge et al. 2009; Hunt, 2012; Sebba and Robinson,_2010; Sizmur et al,_2011).

However, the response from policy-makers in England, for example, has, on the whole, been to retreat from these themes to the promotion of 'British values' and 'character education', an even narrower curriculum focus and a more directed knowledge focus. Since 2010, global issues and sustainability themes have gone from the curriculum in England, the retention of citizenship has been reduced to learning about national political structures. Successful initiatives such as 'sustainable schools' no longer have political support.

The one positive light has been the creation of the Global Learning Programme. This is a five-year programme, funded by the Department for 
International Development which aims to reach $50 \%$ of all state schools in the UK. This article aims to situate the emergence of this progamme within the broader traditions and history of global and development education, summarise where and how schools are making reference to global themes in the curriculum and to review the evidence to date from this Global Learning Programme in terms of impact on the learning of pupils and teachers with particular focus on a whole school approach.

\section{Roots in Global and Development Education}

Learning about the wider world has been part of school-based education for many years. This learning has tended to be influenced by two educational traditions, one with an emphasis on an internationalist and world outlook and the other influenced by de-colonisation and debates within international development. The former, predominantly a post-1945 educational reaction to war and conflict. The creation of international institutions such as the UN and UNESCO led to what was initially called international education, but since the 1980s has been termed global education. This approach, influenced particularly by the work of American educationalists, Hanvey and Tye and UK academics Pike, Selby and Hicks promoted an approach to education that is child-centred with an emphasis on attitudes and skills development and which aims to incorporate a range of concepts such as human rights, sustainability, citizenship, inter-cultural understanding and peace. A variation of this approach has become very influential within Europe as a result of endorsement from the Council of Europe that has put a specific focus on social justice and 'opening people's eyes to the realities of the world' (Osler and Vincent, 2003)

The second tradition is that of development education which emerged in the 1960s and 1970s alongside aid and development programmes and the desire of governments and international non-government organisations to secure public support for and understanding of development and global issues. Influenced particularly by the work of Paulo Freire, development education moved from being an approach to learning that merely transmitted information about development issues to a critical engagement with the area and the emergence of terms such as social justice and education been seen as a vehicle for social change (Bourn, 2015).

At the beginning of the twenty first century, as a result of the impact of globalisation, the term 'global' became the most commonly used way of encouraging learning about the wider world. The result has been the emergence of terms such as global citizenship, global learning and the global dimension within education with the coming together of the international/global and development education traditions.

In the UK, a range of civil society organisations emerged from the 1980s onwards to provide support to schools and teachers in promoting learning about the wider world in the classroom. These included a network of local Development Education Centres, specialist agencies focusing on particular subjects such as human rights and peace and the creation of development 
education departments within the leading international NGOs such as Oxfam. There were also a number of initiatives such as the World Studies movement in the 1980s and in 1993, the creation of the Development Education Association, since renamed as Think Global. From 1997 to 2010 there was a very strong movement of organisations promoting learning about global and development issues throughout the UK, funded by the Department for International Development and the European Commission through a wide range of projects and with the active endorsement of the Department for Education. This however changed in 2010 with the election of the Coalition government - funding ended for projects led by civil society organisations and there was little or no promotion or support from the Department for Education.

\section{Terminology}

A range of terms have been used to promote this learning about the wider world. The most popular between 2000 and 2010 was the term 'global dimension' which was promoted by the Department for Education and was defined as promoting learning about living in an interdependent world with a focus on eight concepts: global citizenship, sustainable development, social justice, diversity, values and perceptions, interdependence, conflict resolution and human rights (DfES, 2000, 2005).

Whilst there is evidence that the Global Dimension was popular amongst many teachers and schools, there was a tendency for it to be used in a 'tickbox' way, treating each concept as a topic or theme for a lesson rather than as a pedagogical approach. It also led to a rather uncritical approach towards learning about development and poverty (Bourn and Hunt, 2011).

Another term that has become part of common usage has been that of 'global citizenship'. The main promoters of this term have been Oxfam who, through their educational programme, have aimed to make a linkage between learning and active engagement in society. To them the concept of 'being a global citizen' includes not only being aware of the wider world, but has a sense of their role within it as a world citizen and is committed to social justice (Oxfam, 2015).

Evidence emerged from a range of studies of an over-emphasis within much of this practice on a rather superficial approach towards learning, not giving sufficient attention to deepening knowledge, but also not recognizing the importance of different viewpoints and perspectives nor encouraging critical reflection.

As a result of this review of these terms and concepts, the following is what this author now sees as the basis for a global learning approach:

- A sense of a global outlook

- $\quad$ A recognition of power and inequality in the world

- $\quad$ A belief in social justice and equity

- A commitment to reflection and dialogue (Bourn, 2015).

Variations on this approach can be seen in Peterson and Warwick (2015) where they refer to 'global learning for global citizenship' with a particular 
emphasis on interconnectedness, cultural diversity, social justice and sustainable development. Think Global emphasise more the processes of learning and change, defining global learning as education that puts learning in a global context, fostering:

- critical and creative thinking;

- self-awareness and open-mindedness towards difference;

- understanding of global issues and power relationships; and optimism and action for a better world"(Think Global, 2015).

Within these slightly different interpretations, there is an underlying consensus that has emerged about what is seen as global learning and this can be seen in the definition and approach used within the Global Learning Programme for England which refers to learning 'about international development through recognising the importance of linking people's lives throughout the world' and the encouragement of a 'critical examination of global issues and an awareness of the impact that individuals can have on them' (GLP-England, 2015).

Before reviewing the impact of this Programme to date, this article now aims to clarify what could be seen as 'global learning' within the curriculum.

\section{Global Learning and the School Curriculum}

Whilst learning about global issues and themes can be seen in all schools, the tendency has been for the humanities, Personal Social and Health Education and foreign languages to be the main subject areas delivering this area (Hunt and Cara, 2015a). The other form in which global learning themes have tended to be promoted is through a series of initiatives or activities such as award programmes ${ }^{1}$, special projects like fundraising or an international link. There has also been an emphasis within many schools to focus on awareness and exposure to different cultures (Edge et al, 2009) or to look at what could be interpreted as the 'softer' ends of global learning (Andreotti, 2006), including the environment and peace rather than the more 'critical' and controversial areas such as addressing an understanding of power and inequality in the world (Bourn and Hunt, 2011; Hunt, 2012). There has been a tendency, therefore, for less attention to be given to approaches that focus directly on teaching and learning. If global learning is to be recognised as a pedagogical approach rather than just a series of themes or topics within a subject, then it needs to be reflected across all aspects of the curriculum and become part of the ethos of the school. This means identifying ways in which global learning can be brought into subjects such as Mathematics through, for example, the exploration of datasets on poverty and inequality, reflecting on how the data has re-enforced or changed perceptions about these issues. But it is often through a more cross-curricula approach that some of the most effective global learning takes place by looking at specific topics such as water, food or shelter through different lenses, perspectives and subjects (see GLP,n.d a, b).

1 There are many such award programmes, more details about these can be found in Bourn, Hunt, Blum and Lawson, 2015) 
There is a growing body of evidence that shows the extent to which more and more schools are recognising that global learning is important to their teaching and learning. Sir John Lawes School, Harpenden in Hertfordshire for example has invested in this area for a number of years with an Advanced Skills Teacher having global and sustainability themes as their remit. The school consciously plans a calendar of activities on global and sustainability themes and puts a particular focus on pupil voices through school councils and specialist interest groups. Evidence from the school also suggests that global learning has helped to improve communication skills and a sense of responsibility amongst the pupils. (GLP, n.d. a: 16)

A good example of a primary school incorporating global learning is Buntingsdale Primary School in Shropshire. At Buntingsdale the global dimension is seen 'more of a thread that weaves throughout much of the curriculum'. Its 2015 Ofsted inspection stated,

The school uses global education themes very effectively to set pupils' learning in a worldwide context and broaden their views of the world. This makes the learning more relevant and interesting for pupils, and so it contributes to their enthusiasm for learning. (Ofsted, 2015:6)

These examples suggest that where there is broader engagement within the school that global learning can be more effective.

Global learning as outlined in this article also poses challenges to many teachers and educationalists. It could be argued that one of its aims is to challenge dominant assumptions within society about aid, development and the lives of people living in poverty. As stated by this author elsewhere, global learning should be about encouraging an approach towards learning that "moves from a charity mentality to one of social justice", that recognizes the value of looking at issues from different perspectives and viewpoints which may well lead to some self-reflection and personal transformation (Bourn, 2015)

\section{The Whole School Approach}

The evidence of greatest impact of global learning within a school has been where global themes are recognised as part of the ethos of the school and are incorporated within as many aspects of school life as possible; from individual lessons $_{1}$ to assemblies, to extra curricular activities and to the ways in which subjects are taught (Hunt and King, 2015). This whole-school approach can be summarized as involving:

- having a vision for global learning

- using a reflective planning process to embed work

- connecting work across different spaces within school

- involving people across the whole community

- embedding global learning into general practice (Hunt and King, 2015). 
For example Hunt (2012), in her study on global learning within primary schools, showed that where global learning was included within many aspects of school life and activities, it was likely to have a greater impact. Similar evidence can be found from the evaluation of the impact of UNICEF's Rights and Respecting School Award (Sebba and Robinson, 2010).

\section{Main Components of Global Learning Programme}

It is in addressing these challenges of including global learning as being part of the ethos of the school that has been central to The Global Learning Programme that has as its purpose:

to equip children and young people to make a positive contribution to a globalized world by helping their teachers to deliver effective teaching and learning about development and global issues at key stage 2 and 3 (GLP, 2015)

There are four separate Global Learning Programmes, running in England, Scotland, Wales and Northern Ireland. While each programme is tailored to fit in with the educational priorities of that country there are commonalities across all four programmes. Each programme is delivered by a consortium of organisations, including educational consultancy bodies with NGOs and subject-based associations. A whole school approach to global learning (Hunt and King, 2015) is central to the programmes. Due to the influence of the funder, DFID, each programme has a specific focus on learning about global poverty and international development issues, albeit through the encouragement of different lenses and perspectives. There is a strong focus in each programme on the professional development of teachers (GLP Wales, n.d.; GLP-E, 2015).

\section{The focus of this article, and the evidence now referred to all comes from the}

Global Learning Programme in England. This Programme is based around the development of a network of schools as expert centres who then support local partner schools in embedding global learning through a structured professional development and support programme. All schools who join the programme have to complete an online whole school audit which aims to help the school assess its current level of expertise and activity and provide it with an action plan to develop further its skills and knowledge in global learning. At the completion of an eighteen-month cycle of activity, the school then re-visits the audit to assess the progress it has made (Hunt and King, 2015).

Schools can then, once they have completed this audit, access funding to gain further professional development support and courses from accredited organisations.

The second element of the Programme is the focus on pupils' learning and the outcomes expected from this learning. Within the programme this is again a specific focus on acquiring knowledge about the causes of global poverty and uneven development, the skills to engage with these issues and an 
exploration of their own and other peoples' values related to global issues such as fairness, human rights and tolerance.

Evidence of learning about these themes is assessed through pupils completing the GLP Pupil Assessment Tool, which is an online activity to explore their knowledge about global learning themes. This activity is undertaken twice, at the beginning and end of the academic year with a view to measuring progress and change in pupils' knowledge and understanding.

\section{Evidence of the Impact of the Programme on Schools}

Whilst the Global Learning Programme only effectively got under way in 2013 and evidence takes time to emerge, the following themes of progress to date can be identified.

Firstly, there is considerable evidence of school engagement within the programme. There are over 3000 involved (September 2015) which means that it is beginning to reach beyond those schools who already had considerable experience in global learning. This level of interest is encouraging particularly in the light of the contrary priorities of many of the policies coming out from UK government.

Secondly, there is evidence, from the completed whole school audits to date, of increased engagement with global learning across the schools, moving beyond specific activities to recognising the importance of ethos and broader pedagogical approach (Hunt and Cara, 2015a,b).

Thirdly, from a number of case studies and in-depth research, there is evidence emerging that changes can and do take place in terms of approaches toward teaching and learning (Bourn, 2014). This seems to occur as schools begin a process of reflection upon their approach to learning about global issues and to engage with issues such as the causes of poverty and inequality in the world, moving beyond an approach based on 'fundraising and having fun',

Fourthly engagement with the Global Learning Programme appears to have enthused many teachers who recognise that there is more to teaching than testing and examinations and that learning about the wider world can provide real meaning to the purpose of teaching.

\section{FROM HERE}

An example of the specific impact of the Global Learning Programme on a primary school can be seen from the research by Alcock and Ramirez Barker (2015) through literacy. The conclusions of their action research project which aims to see the impact on global learning methodologies on pupils' writing shows the following:

- Increased opportunities for talking - discussion, debating and exploratory talk - has led to pupil progress within writing, for example adding detail and description and through well documented pupil progress data 
- The enthusiasm pupils' show for global learning and Development Education methodologies has been harnessed to bring refreshed motivation for writing, as recorded in pupil feedback and teacher observations of pupils' progress.

- Senior leadership and vision are essential to ensure progress with this type of intervention, where global learning falls outside of the current conceived agenda for raising standards.

What this study also showed is that for the teachers, by being part of a broader professional development community, their confidence and enthusiasm for global learning grew.

Another example of the impact of a programme on a school has been study from a teacher from a primary school that has been actively involved in the Programme. The theme of the research was to look at the impact of global learning on children's perceptions of Africa, particularly the images they had. What the evidence showed was that as a result of a process of learning, children were able to more critically review images from the media on Africa. Also the teacher noted that ' by raising awareness of the diversity found within Africa and drawing their attention to many positive aspects of Africa, pupils were able to draw on the knowledge they had gained rather than rely on stereotypical representations that had previously dominated their thinking (Lewis, 2015).

\section{Conclusion}

Despite a challenging educational climate, global learning is clearly having an impact with many schools in England. Development education and global learning emerged from a desire by governments and NGOs to secure greater understanding of international development issues. Today it has become much more mainstream and related directly to the needs of children and young people to make sense of the world in which they are living. It is where schools are moving beyond 'fundraising, fasting and having fun' (Bryan and Bracken, 2011) to see learning about the wider world as related to current values debate around fairness, tolerance and rights and responbilities. The Global Learning Programme is clearly providing an important opportunity for schools to not only engage with these themes, but also see them as part of the everyday life and practice of the school. As pupils from one London school have commented:

\section{'Learning on the international scale allows us to broaden our horizons and understanding of different viewpoints, not just our own. It opens your eyes without realizing it' (GLP-E, a:11)}

\section{Author:}

Douglas Bourn is Director of Development Education Research Centre at UCL-IOE. His most recent publication is The Theory and Practice of Development Education and he has been editor of the international Journal of Development Education and Global Learning and numerous articles on themes such as global citizenship, education for sustainable development and global perspectives within education. Contact details: d.bourn@ioe.ac.uk 


\section{References:}

Alcock, H. and Ramirez Barker, L. (2015 forthcoming) Can global learning raise standards within pupils' writing in the primary phase? London: UCL Institute of Education.

Andreotti, V. (2006) Soft versus critical global citizenship education. Policy and Practice: A Development Education Review, 3: 40-51.

Bourn, D. (2014) School Linking and Global Learning - Teachers' Reflections. DERC Research Paper no.12. London: UCL Institute of Education.

Bourn, D. (2015) The Theory and Practice of Development Education: A pedagogy for global social justice. Abingdon: Routledge.

Bourn, D. and Hunt, F. (2011) The Global Dimension in Secondary Schools, DERC Research Paper no.1, London, IOE.

Bryan, A. and Bracken, M. (2011) Learning to Read the World, Dublin, Irish Aid.

DfES $(2000,2005)$ Developing the Global Dimension within the School Curriculum, London, DFES

Edge, K., Khamsi, K. and Bourn, D. (2009) Exploring the Global Dimension in Secondary Schools: Final Research Report. London: Institute of Education.

GLP-E (2015) Global Learning Programme England. [Online] Available from: www.glp-e.org.uk [Accessed: 1 September, 2015].

GLP-E (n.d.a) Global Learning Programme Secondary Senior Leadership Team Pack, London, Pearson

GLP E (n.d.b) Global Learning Programme Primary Senior Leadership Team Pack, London, Pearson

GLP Wales (n.d.) Global Learning Programme Wales. [Online] Available from: http://globaldimension.org.uk/glpwales/page/10839 [Accessed: 1 September, 2015].

Hicks, D. \& Holden, C. (Ed.) (2007) Teaching the Global Dimension: Key principles and effective practice. Abingdon: Routledge.

Hunt, F. (2012) Global Learning in Primary Schools in England: Practices and Impacts. DERC Research Paper no. 9. London: UCL Institute of Education.

Hunt, F. and Cara, O. (2015a, forthcoming) Global Learning in England:

Analysis of the Global Learning Programme Whole School Audit 2013-14.

London: UCL Institute of Education.

Hunt, F. and Cara, O. (2015b, forthcoming) Global Learning in England:

Analysis of the Global Learning Programme Whole School Audit 2013-15 -

Practices and impacts. London: UCL Institute of Education. 
Hunt, F. and King, R. P. (2015) Supporting whole school approaches to global learning: focusing learning and mapping impact. DERC Research Paper no. 13. London: UCL Institute of Education.

Lewis, M. (2015) (forthcoming) A study of a focused, critical approach to pupils' images and perceptions of Africa- GLP Innovation Fund Research Paper, London: GLP-E.

OFSTED (2015) Buntingsdale Primary School and Nursery, Inspection Report. Manchester: OFSTED

Osler, A. and Vincent,_K._(2002) Citizenship and Global Education, Stoke-onTrent, Trentham Books

Oxfam (2015) Education for Global Citizenship: A Guide for Schools. Oxford: Oxfam.

Petersen, A. and Warwick, P. (2015) Global Learning and Education: key concepts and effective practice, Abingdon, Routledge

Sebba, J. and Robinson, C. (2010) Evaluation of UNICEF UK's Rights Respecting Schools Award. London: UNICEF UK.

Sizmur, J., Brzyska, B., Cooper, L., et al. (2011) Global School Partnerships Programme: Impact evaluation report. Slough: NFER.

Think Global (2015) About Global Learning, http://think-global.org.uk/globallearning/theory-of-change/ (accessed 6 October, 2015) 